\title{
Variability of the mc1r Gene in Melanic and Non-Melanic Podarcis liffordi and Podarcis pityusensis from the Balearic Archipelago
}

\author{
Joana M. Buades ${ }^{1}$, Virginia Rodríguez' ${ }^{1}$, Bàrbara Terrasa' ${ }^{1}$, Valentin Pérez-Mellado², Richard P. Brown ${ }^{3}$, \\ Jose A. Castro ${ }^{1}$, Antònia Picornell ${ }^{1}$, M. M. Ramon ${ }^{1 *}$
}

1 Laboratori de Genètica, Universitat de les Illes Balears, Palma de Mallorca, Spain, 2 Departamento de Biología Animal, Universidad de Salamanca, Salamanca, Spain, 3 School of Natural Sciences and Psychology, Liverpool John Moores University, Liverpool, United Kingdom

\begin{abstract}
The association between polymorphism at the mc1r locus and colour variation was studied in two wall lizard species (Podarcis lilfordi and P. pityusensis) from the Balearic archipelago. Podarcis lilfordi comprises several deep mitochondrial lineages, the oldest of which originated in the Pliocene, while much shallower mitochondrial lineages are found in $P$. pityusensis. Here, we examined whether specific substitutions were associated with the melanic colouration found in islet populations of these species. Homologous nuclear sequences covering most of the mc1r gene were obtained from 73 individuals from melanic and non-melanic Podarcis from different populations (the entire gene was also sequenced in six selected individuals). MtDNA gene trees were also constructed and used as a framework to assess mc1r diversity. Mc1r showed greater polymorphism in P. lilfordi than in P. pityusensis. However, we observed no substitutions that were common to all melanic individuals across the two species. Only one significant association was detected in the mc $1 r$ partial sequence, but this was a synonymous $A / G$ mutation with $A$ alleles being more abundant in melanic populations. In addition, there were no associations between the main dominant phenotypes (green and brown, blue and yellow spots and ventral colour) and synonymous or non-synonymous substitutions in the mc1r gene. There was no statistical evidence of selection on $m c 1 r$. This study suggests no relationship between mc1r polymorphism and colour variation in Balearic Podarcis.
\end{abstract}

Citation: Buades JM, Rodríguez V, Terrasa B, Pérez-Mellado V, Brown RP, et al. (2013) Variability of the mc1r Gene in Melanic and Non-Melanic Podarcis lilfordi and Podarcis pityusensis from the Balearic Archipelago. PLoS ONE 8(1): e53088. doi:10.1371/journal.pone.0053088

Editor: Keith A. Crandall, George Washington University, United States of America

Received June 15, 2012; Accepted November 27, 2012; Published January 7, 2013

Copyright: (c) 2013 Buades et al. This is an open-access article distributed under the terms of the Creative Commons Attribution License, which permits unrestricted use, distribution, and reproduction in any medium, provided the original author and source are credited.

Funding: This work has been financed by the research funds CGL2006-10893 and CGL2009-12926 of the Spanish Ministerio de Ciencia e Innovación and European Union FEDER funds. VR is supported by a grant from Direcció General URT (Govern de les Illes Balears) and European Union FSE. The funders had no role in study design, data collection and analysis, decision to publish, or preparation of the manuscript.

Competing Interests: The authors have declared that there are no competing interest exist.

*E-mail: cori.ramon@uib.es

\section{Introduction}

Although environmental stimuli can contribute to colour variation within species, most of this variation appears to be genetically controlled [1]. Molecular analyses are starting to reveal mutations associated with melanism in wild populations. In some birds and mammals, melanism seems to be associated with amino acid substitutions in the melanocortin-1 receptor $(m c 1 r)$, a gene known to control the synthesis of melanin by melanocytes [2,3]. The agouti-melanocortin 1 receptor pathway is a ligand receptor pair that modulates the amount and type of pigment produced by melanocytes (red/yellow pheomelanin or brown/black eumelanin). Genetic subtypes of $m c r$ genes (of which $m c 1 r$ is one) have high structural similarity. The majority of them seem to have originated early in vertebrate evolution before the divergence of ray-finned fishes and tetrapods [4]. The main structural properties of these genes have remained remarkably conserved over a period of at least 400 million years [4]. Gain-of function and/or deletion mutations in the $m c 1 r$ locus are well recognized causes of melanism [5]. For example, a deletion in the $m c 1 r$ gene explains melanism in squirrels [6]. In birds, Guo et al. [7] reported abundant polymorphism in the $m c 1 r$ gene which was associated with black plumage in Hebei chickens. Different mutations in the $m c 1 r$ gene also explain the brown phenotype in the cavefish, Astyanax mexicanus [8].

Several studies have recently addressed the $m c 1 r$ gene and colour polymorphism in amphibians and reptiles. Three independent $m c 1 r$ mutations (His ${ }^{208} \mathrm{Tyr}, \mathrm{Thr}^{170} \mathrm{Ile}$, and $\mathrm{Val}^{168} \mathrm{Ile}$ ) are responsible for blanched coloration of three lizard species on the gypsum dunes of White Sands, New Mexico, where they are associated with melanin production in the species Holbrookia maculata, Aspidoscelis inornata and Sceloporus undulatus [9]. Although the same gene contributes to light phenotypes in these White Sands populations, the specific molecular mechanisms leading to reduced melanism production appear to be different. In contrast, sequence variation in $m c 1 r$ does not explain melanism in the widespread amphibian Rana temporaria [10] nor does it appear to be involved in dorsal colour adaptations in two sympatric species of sand lizard (Liolaemus) that inhabit the south eastern coast of South America [11] or colour pattern in Uta lizards [12]. Some authors consider blue colouration to be a form of melanism in reptiles [13]. However the blue abdominal skin seen in several lizards is a sexually dimorphic trait that is more pronounced in males [14] and is attributed to eliciting a behavioural response in the observer [15]. Recently, an association between $m c 1 r$ variants and brown 
Table 1. Colour patterns of the different lizard populations.

\begin{tabular}{|c|c|c|c|c|c|c|c|c|c|c|c|c|c|}
\hline & \multirow[t]{3}{*}{$\begin{array}{l}\text { LOCALIZA- } \\
\text { TION }\end{array}$} & \multirow[t]{3}{*}{$\begin{array}{l}\text { POPULA- } \\
\text { TIONS }\end{array}$} & \multicolumn{6}{|c|}{$\begin{array}{l}\text { DORSAL } \\
\text { COLOUR }\end{array}$} & \multicolumn{5}{|c|}{$\begin{array}{l}\text { VENTRAL } \\
\text { COLOUR }\end{array}$} \\
\hline & & & \multirow[t]{2}{*}{ Brown } & \multirow[t]{2}{*}{ Green } & \multirow[t]{2}{*}{ Black } & \multirow[t]{2}{*}{ Dominant } & \multicolumn{2}{|c|}{ Spots } & \multirow[t]{2}{*}{ Light } & \multirow[t]{2}{*}{ Dark } & \multirow[t]{2}{*}{ Blue } & \multirow[t]{2}{*}{ Orange } & \multirow[t]{2}{*}{ Blue Oce. } \\
\hline & & & & & & & Blue & Yellow & & & & & \\
\hline \multirow[t]{13}{*}{$\begin{array}{l}\text { Podarcis } \\
\text { lilfordi }\end{array}$} & $\begin{array}{l}\text { CABRERA } \\
\text { ARCHIPELAGO }\end{array}$ & Cabrera & $x$ & $x$ & & Brown & & & $x$ & & $\mathrm{x}$ & & $\mathrm{x}$ \\
\hline & & Foradada & & & $x$ & Black & $\mathrm{x}$ & & & $\mathrm{x}$ & $\mathrm{x}$ & & \\
\hline & MALLORCA & Dragonera & $x$ & $\mathrm{x}$ & & Brown & & & $x$ & & & $x$ & $x$ \\
\hline & & El Toro & $\mathrm{x}$ & & & Brown & & & $x$ & & & & $x$ \\
\hline & & Colomer & & & $x$ & Black & & & & $x$ & $x$ & & \\
\hline & & Guardia & & & $\mathrm{x}$ & Black & $\mathrm{x}$ & & & $x$ & $\mathrm{x}$ & & \\
\hline & & Moltona & & & $x$ & Black & $x$ & & & $\mathrm{x}$ & $\mathrm{x}$ & & \\
\hline & & Malgrats & $x$ & & $x$ & Black & & & & $x$ & $x$ & & $\mathrm{x}$ \\
\hline & MENORCA & Addaia & $x$ & $x$ & & Green & $\mathrm{x}$ & & $x$ & & & & $\mathrm{x}$ \\
\hline & & Binicodrell & $x$ & $\mathrm{x}$ & & Brown & & $x$ & & $x$ & & $x$ & $\mathrm{x}$ \\
\hline & & Rei & $x$ & $x$ & & Brown & & $\mathrm{x}$ & $x$ & & & & $x$ \\
\hline & & Sanitja & $\mathrm{x}$ & $x$ & & Brown & & & & & & $\mathrm{x}$ & \\
\hline & & Aire & $\mathrm{x}$ & & $\mathrm{x}$ & Black & $\mathrm{x}$ & & & $x$ & $\mathrm{x}$ & & $\mathrm{x}$ \\
\hline \multirow[t]{14}{*}{$\begin{array}{l}\text { Podarcis } \\
\text { pityusensis }\end{array}$} & IBIZA & Alga & $\mathrm{x}$ & $\mathrm{x}$ & & Brown & & & $x$ & & & & $\mathrm{x}$ \\
\hline & & Bosc & $x$ & $x$ & $x$ & Green & $x$ & & & $x$ & & $\mathrm{x}$ & $\mathrm{x}$ \\
\hline & & Conillera & $\mathrm{x}$ & $\mathrm{x}$ & & Green & $x$ & $x$ & $x$ & & $x$ & & $x$ \\
\hline & & Dau Gran & & $\mathrm{x}$ & $\mathrm{x}$ & Green & $x$ & $x$ & & $x$ & $\mathrm{x}$ & & $\mathrm{x}$ \\
\hline & & Eivissa & $x$ & $x$ & & Green & & & $\mathrm{x}$ & & & $\mathrm{x}$ & $\mathrm{x}$ \\
\hline & & Espartar & $x$ & $x$ & $x$ & $\begin{array}{l}\text { Green- } \\
\text { Brown }\end{array}$ & $x$ & $\mathrm{x}$ & & $\mathrm{x}$ & $\mathrm{x}$ & $\mathrm{x}$ & $\mathrm{x}$ \\
\hline & & Espalmador & $x$ & $x$ & & Green & & & $x$ & & & & $x$ \\
\hline & & S. Josep & $\mathrm{x}$ & $x$ & $\mathrm{x}$ & Green & & $x$ & $\mathrm{x}$ & & & $\mathrm{x}$ & $\mathrm{x}$ \\
\hline & & Bleda Plana & & & $x$ & Black & & & & $\mathrm{x}$ & $\mathrm{x}$ & & \\
\hline & & Escull Vermell & & & $\mathrm{x}$ & Black & $x$ & & & $x$ & $\mathrm{x}$ & & \\
\hline & FORMENTERA & Cap Barberia & $x$ & $x$ & $x$ & Green & & $x$ & $x$ & & & $x$ & $x$ \\
\hline & & P.Trocadors & $x$ & $x$ & & Brown & & & $\mathrm{x}$ & & & $x$ & $x$ \\
\hline & & Sa Pujada & $\mathrm{x}$ & $x$ & $\mathrm{x}$ & Green & & $\mathrm{x}$ & $\mathrm{x}$ & & & $\mathrm{x}$ & $\mathrm{x}$ \\
\hline & & St F. Xavier & $\mathrm{x}$ & $x$ & & Green & $\mathrm{x}$ & $x$ & $x$ & & $x$ & & $\mathrm{x}$ \\
\hline \multirow[t]{3}{*}{$\begin{array}{l}\text { Podarcis } \\
\text { tiliguerta }\end{array}$} & & Foradada & $x$ & $x$ & & Brown & & $x$ & $x$ & & & $\mathrm{x}$ & \\
\hline & & Padodell & $\mathrm{x}$ & $x$ & & Brown & & $\mathrm{x}$ & $x$ & & & $\mathrm{x}$ & \\
\hline & & Stramari & $x$ & $\mathrm{x}$ & & Brown & & $\mathrm{x}$ & $\mathrm{x}$ & & & $\mathrm{x}$ & \\
\hline \multicolumn{2}{|c|}{ Podarcis filfolensis } & Comino & $x$ & $x$ & $\mathrm{x}$ & Brown & $\mathrm{x}$ & & $x$ & & & $x$ & $x$ \\
\hline
\end{tabular}

Melanic populations are indicated by grey shading.

doi:10.1371/journal.pone.0053088.t001

scale colour phenotypes has been described in the European ocellated lizard, Lacerta lepida (Timon lepidus) [16].

The genus Podarcis is one of the most diverse and abundant reptile groups in southern Europe, with more than 20 currently recognized species $[17,18]$, and since the early works of Einer [19] has been known to contain several species that contain melanic populations. Melanic lizards and darker individuals in general, were originally thought to be associated with older island populations [19,20,21].

Two endemic species of Podarcis inhabit the Balearic Archipelago: Podarcis lilfordi in the Eastern Gymnesic Islands group
(Mallorca, Menorca, Cabrera and their coastal islets) and Podarcis pityusensis in the Western Pityusic group (Ibiza, Formentera and coastal islets). Phylogenetic analyses have showed geographical structuring of mtDNA among insular populations of $P$. lilford $i$ with four main intraspecific lineages, the first of which diverged some $2.6 \mathrm{Ma}[22,23]$. Divergence within $P$. pityusensis is more recent with the main Ibiza and Formentera clades sharing a common ancestor around $1 \mathrm{Ma}$ ago $[22,23]$.

Eisentraut [21] described melanic populations of $P$. lilfordi from the islands of Aire (Menorca), and Foradada (Cabrera archipelago), as well as $P$. pityusensis from Bleda Plana [19]. He 
MC1R PROTEIN

Non synonymous changes
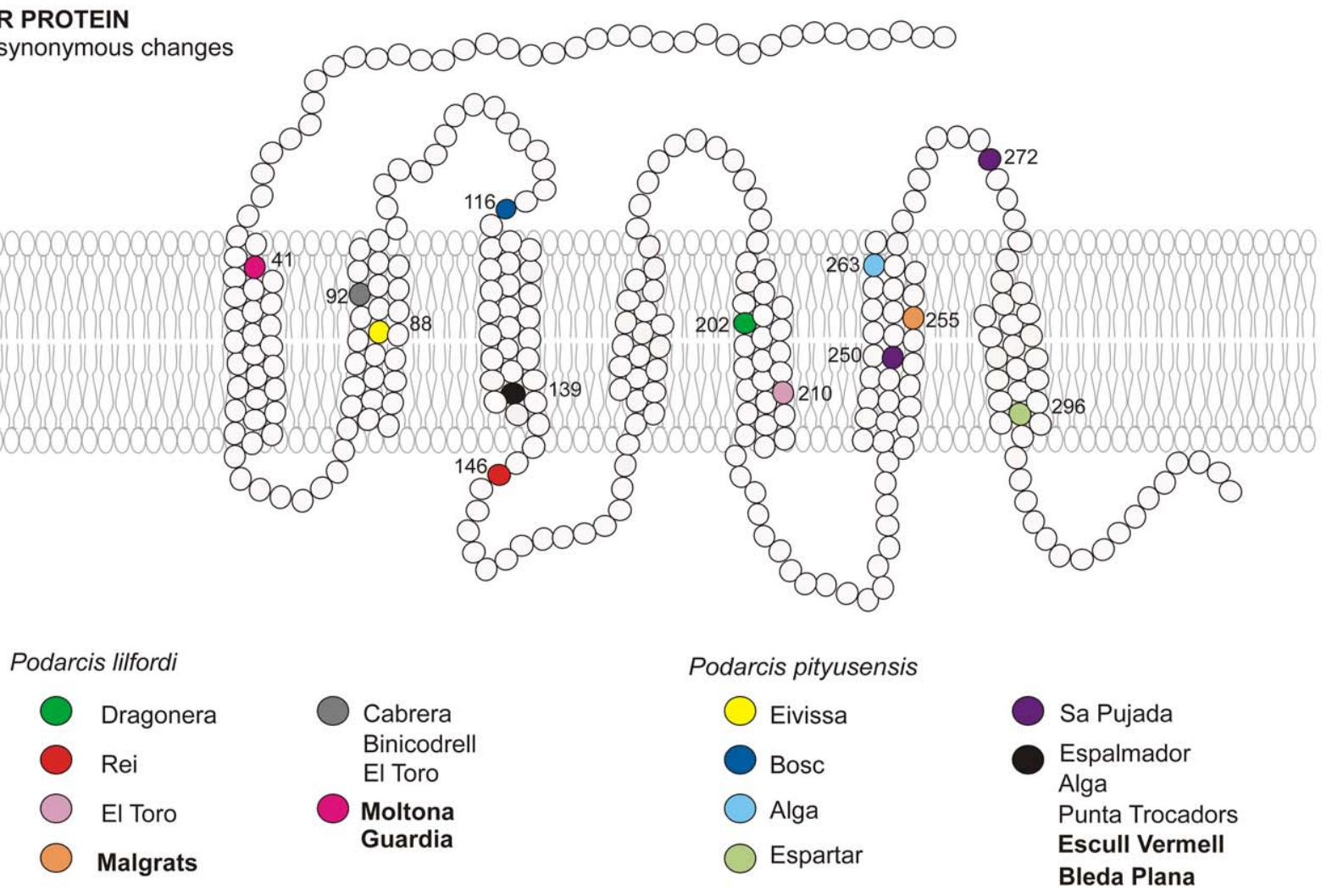

Figure 1. MC1R amino acid substitutions detected in $P$. liffordi and $P$. pityusensis, and their locations relative to the cell membrane (modified from Garcia-Borron et al. [43]). Melanic populations are indicated in bold. doi:10.1371/journal.pone.0053088.g001

hypothesized that dark phenotypes were induced by a higher consumption of plant material. In contrast, Kramer [20] suggested an evolutionary explanation: dark colouration/melanism conveyed adaptive advantages through protection from harmful ultraviolet radiation, while enhancing heat absorption during cooler weather. Later, Hartmann [24] proposed that mutations that caused melanism originated before the coastal islets were separated from the main islands. The high degree of phenotypic variation (body size and colouration) among coastal islets is now well-established [25]. Several coastal islets host melanic populations of $P$. lilfordi, while a smaller number of islets also host melanic or very dark populations of $P$. pityusensis.

The purpose of the present paper was to investigate the putative association between polymorphism at the $m c 1 r$ locus and colour phenotype in Podarcis from the Balearic Islands and therefore establish whether specific substitutions were associated with the melanic colouration of these populations.

\section{Materials and Methods}

\section{Samples}

A sample of 72 individuals from the genus Podarcis was analyzed (Table 1). These were: 1) 46 Podarcis lilfordi from 13 islands and islets corresponding to 7 light insular forms and 6 dark/melanic insular forms (from Mallorca, Menorca and Cabrera), 2) $22 P$. pityusensis from 14 populations (from Ibiza and Formentera) with only two dark/melanic insular populations, 3) three Podarcis tiliguerta (from Corsica, France), and 4) one P. filfolensis (from Comino, Malta). The lizards from Corsica and Comino are light insular forms. A Podarcis sicula mc1r sequence was also available
(Genbank: GU225767). Insular lizard populations were selected so that the most extreme phenotypes were included. All specimens were captured with official permits from national and regional organisms and the lizards released at the point of capture.

\section{Pigmentation Variation}

Variation in pigmentation of the Balearic populations was classified from previous descriptions [25,26]. Several colour characteristics were noted (within-islet variation was negligible for these characteristics). They included the presence of brown, black, green on the dorsum, dark/light ventral colouration and the presence of blue, yellow and orange spots (Table 1).

\section{DNA Extraction, Amplification and Sequencing}

DNA was extracted during previous conservation genetics projects that described the mtDNA diversity within these lizards in order to underpin conservation strategies by the Balearic Islands Autonomous Government [25,26]. A $720 \mathrm{bp}$ fragment of $m c 1 r$ gene was amplified with the forward primer MC1R-PF 5'GGCNGCGATYGTCAANAACGGGAACG- $3^{\prime}$ and the reverse primer MC1R-PR 5'-CTCGGRAAGGCRTAAATNATGGGGTCGAC-3' (modified from Pinho et al., 2010 [27]). A second pair of primers was designed from the Podarcis sicula sequence to obtain the complete $m c 1 r$ sequence $(944 \mathrm{bp})$. The forward primer was 5'-ATGTCTGTGCGATCACGCCT-3' and the reverse primer was 5'-GGTTCGGGTTCTTGACAATGGCNGCG-3'. The same PCR conditions were used for both sets of primers.

PCR reactions were performed in $25 \mu \mathrm{l}$ volumes with $80 \mathrm{ng}$ DNA, $1 \times$ PCR Buffer, $0.4 \mathrm{mM}$ dNTPs, $0.3 \mu \mathrm{M}$ of each primer 
Table 2. Synonymous and non synonymous (in bold) changes.

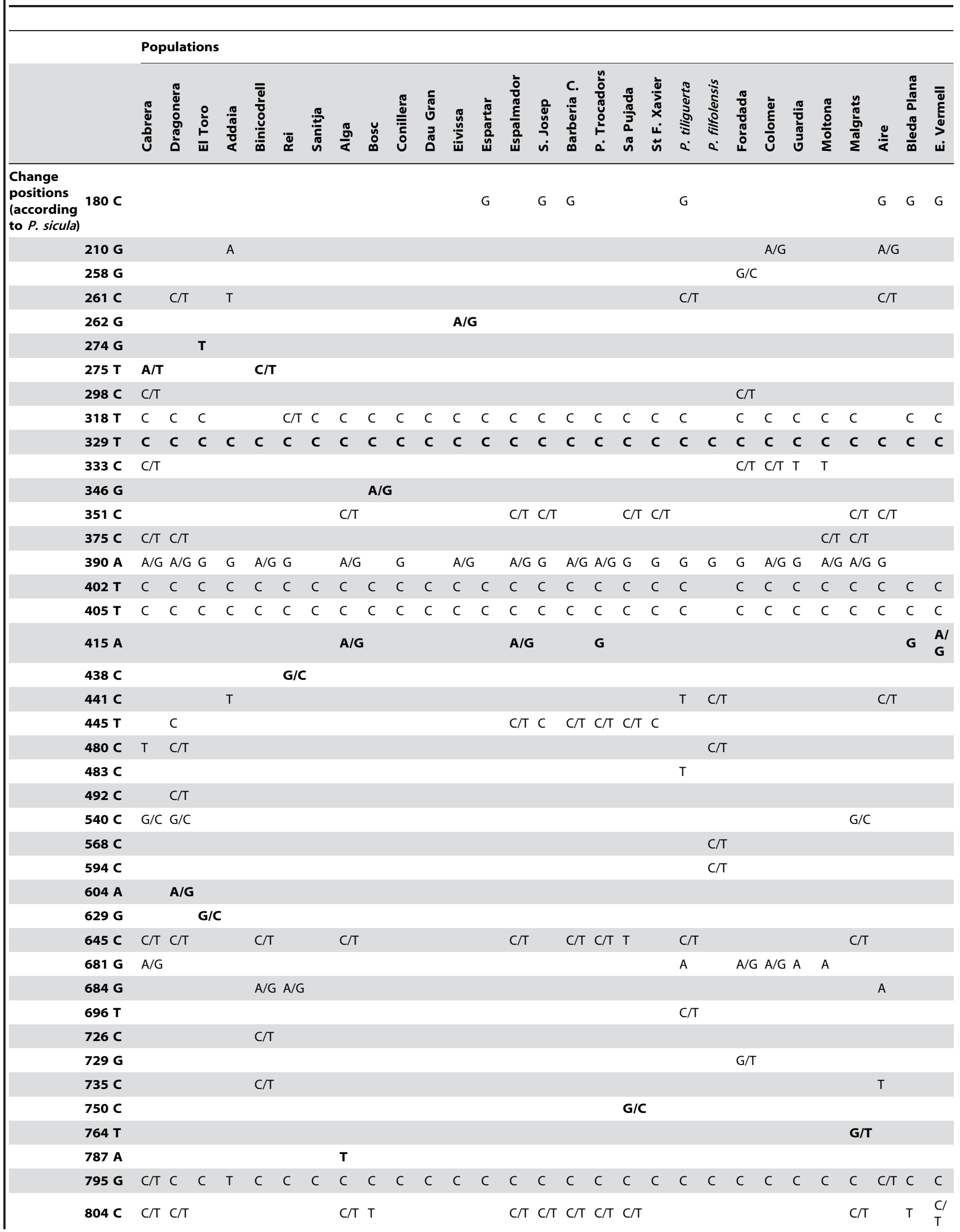


Table 2. Cont.

\begin{tabular}{|c|c|c|c|c|c|c|c|c|c|c|c|c|c|c|c|c|c|c|c|c|c|c|c|c|c|c|c|c|c|}
\hline & \multicolumn{29}{|c|}{ Populations } \\
\hline & $\begin{array}{l}\frac{\pi}{0} \\
\frac{0}{0} \\
\text { Ũ }\end{array}$ & 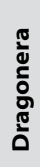 & $\begin{array}{l}\stackrel{\circ}{\circ} \\
\frac{1}{\mathbf{u}}\end{array}$ & $\begin{array}{l}\frac{\pi}{\pi} \\
\frac{\pi}{0} \\
\frac{0}{\alpha}\end{array}$ & 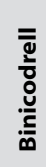 & $\bar{q}$ & 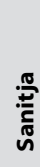 & $\frac{0}{<}$ & पू̆ & 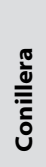 & 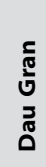 & 氙 & 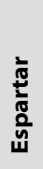 & 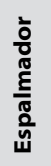 & $\begin{array}{l}\text { वे } \\
\vdots \\
\text { v }\end{array}$ & 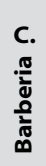 & 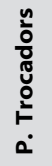 & 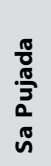 & 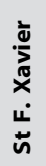 & 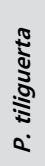 & 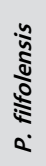 & $\begin{array}{l}\frac{\pi}{0} \\
\frac{\pi}{0} \\
\frac{\pi}{0} \\
\frac{0}{0} \\
4\end{array}$ & غัँ & $\begin{array}{l}\frac{\pi}{0} \\
\frac{\pi}{0} \\
\text { ड़ }\end{array}$ & 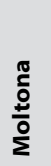 & $\begin{array}{l}\frac{n}{0} \\
\frac{5}{6} \\
\frac{\pi}{20}\end{array}$ & 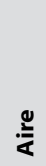 & $\begin{array}{l}\frac{\pi}{\pi} \\
\frac{\pi}{\alpha} \\
\frac{\pi}{\delta} \\
\frac{\pi}{0}\end{array}$ & 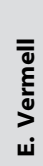 \\
\hline $814 \mathrm{~T}$ & & & & & & & & & & & & & & & & & & $\mathbf{A} / \mathbf{T}$ & & & & & & & & & & & \\
\hline 879 A & C & C & C & C & C & C & C & C & C & C & C & C & C & C & C & C & C & C & C & C & C & C & C & C & C & C & C & C & C \\
\hline $885 C$ & & & & & & & & & & & & $\mathrm{C} / \mathrm{T}$ & & $\mathrm{C} / \mathrm{T}$ & & & $\mathrm{C} / \mathrm{T}$ & & & & & $\mathrm{C} / \mathrm{T}$ & & $\mathrm{C} / \mathrm{T}$ & $\mathrm{C} / \mathrm{T}$ & & & & \\
\hline 886 G & & & & & & & & & & & & & C & & & & & & & & & & & & & & & & \\
\hline
\end{tabular}

Melanic populations are indicated by grey shading.

doi:10.1371/journal.pone.0053088.t002

and 0.5 units of DNA polymerase. PCR conditions were: $5 \mathrm{~min}$ at $92^{\circ} \mathrm{C}, 35$ cycles of $30 \mathrm{~s}$ at $92^{\circ} \mathrm{C}, 30 \mathrm{~s}$ at $56^{\circ} \mathrm{C}, 90 \mathrm{~s}$ at $72^{\circ} \mathrm{C} ; 5 \mathrm{~min}$ at $72^{\circ} \mathrm{C}$. PCR products were purified using the Invitek MSB ${ }^{\circledR}$ Spin PCRapace (Invitek GMBH, Berlin, Germany). Both heavy and light strands were sequenced on an automated ABI 3130 sequencer using a Big Dye ${ }^{\circledR}$ v3.1 Cycle sequencing kit (Applied Biosystems, Foster City CA, USA). Sequence data have been deposited at the GenBank data library under accession numbers JX126622-JX126693.

The following partial mitochondrial genes were also amplified using PCR and sequenced: 12S rRNA, cytochrome $b$ (two regions obtained separately), control region and an $800 \mathrm{bp}$ (ND) fragment that included part of the NDl gene, three tRNA genes, tRNA ${ }^{\text {Ile }}$, tRNA $^{\mathrm{Gln}}$, and $\mathrm{tRNA}^{\mathrm{Met}}$ and part of the ND2 gene. The total length of mitochondrial sequence analyzed for each animal was 2370 bp. We sequenced individuals from P. pityusensis (GenBank

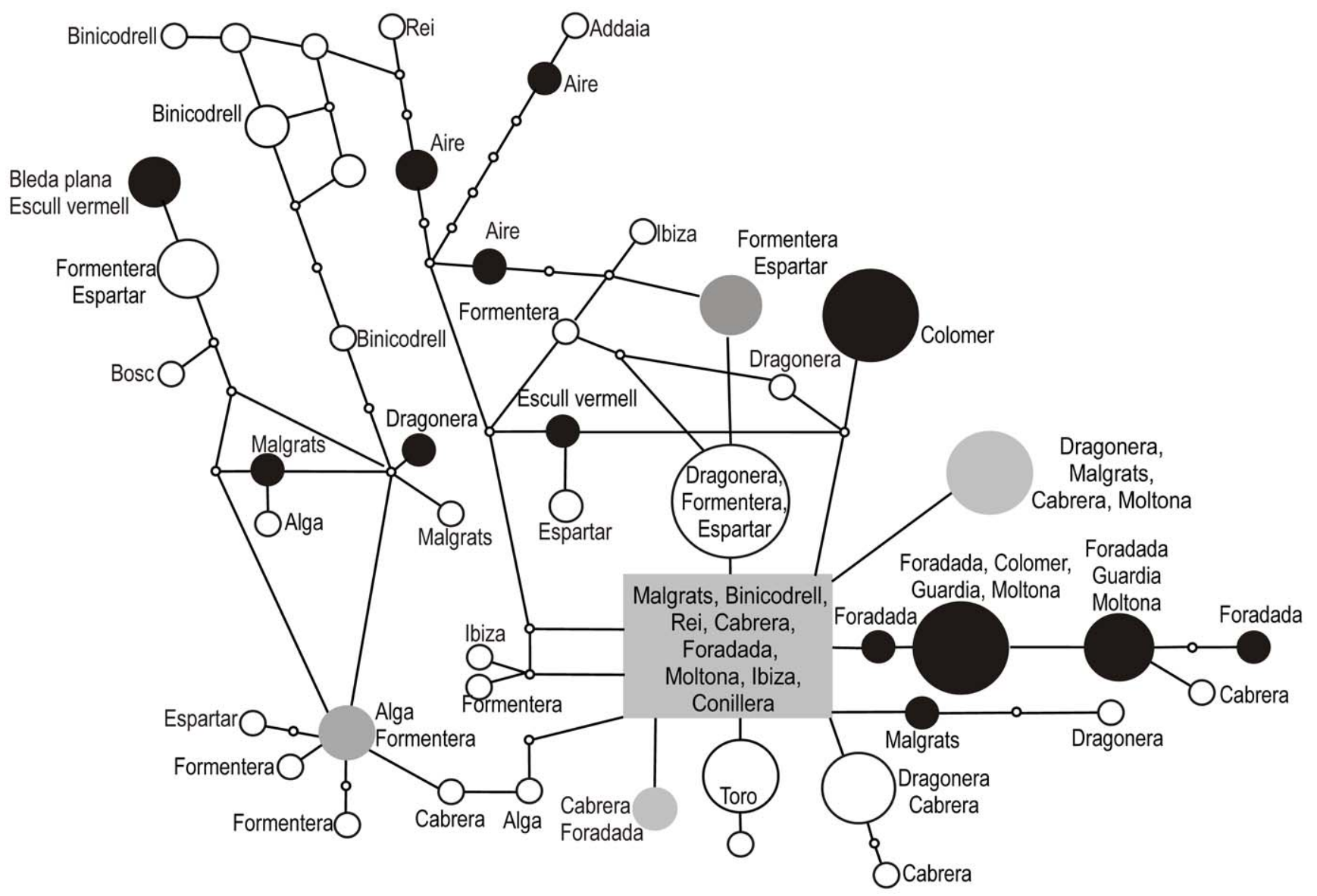

Figure 2. Network showing relationships among $m c 1 r$ haplotypes observed in Balearic populations. Alleles from melanic populations are represented as black circles, and non-melanic populations as white circles. Alleles that were found in both melanic and nonmelanic populations are represented as grey circles.

doi:10.1371/journal.pone.0053088.g002 


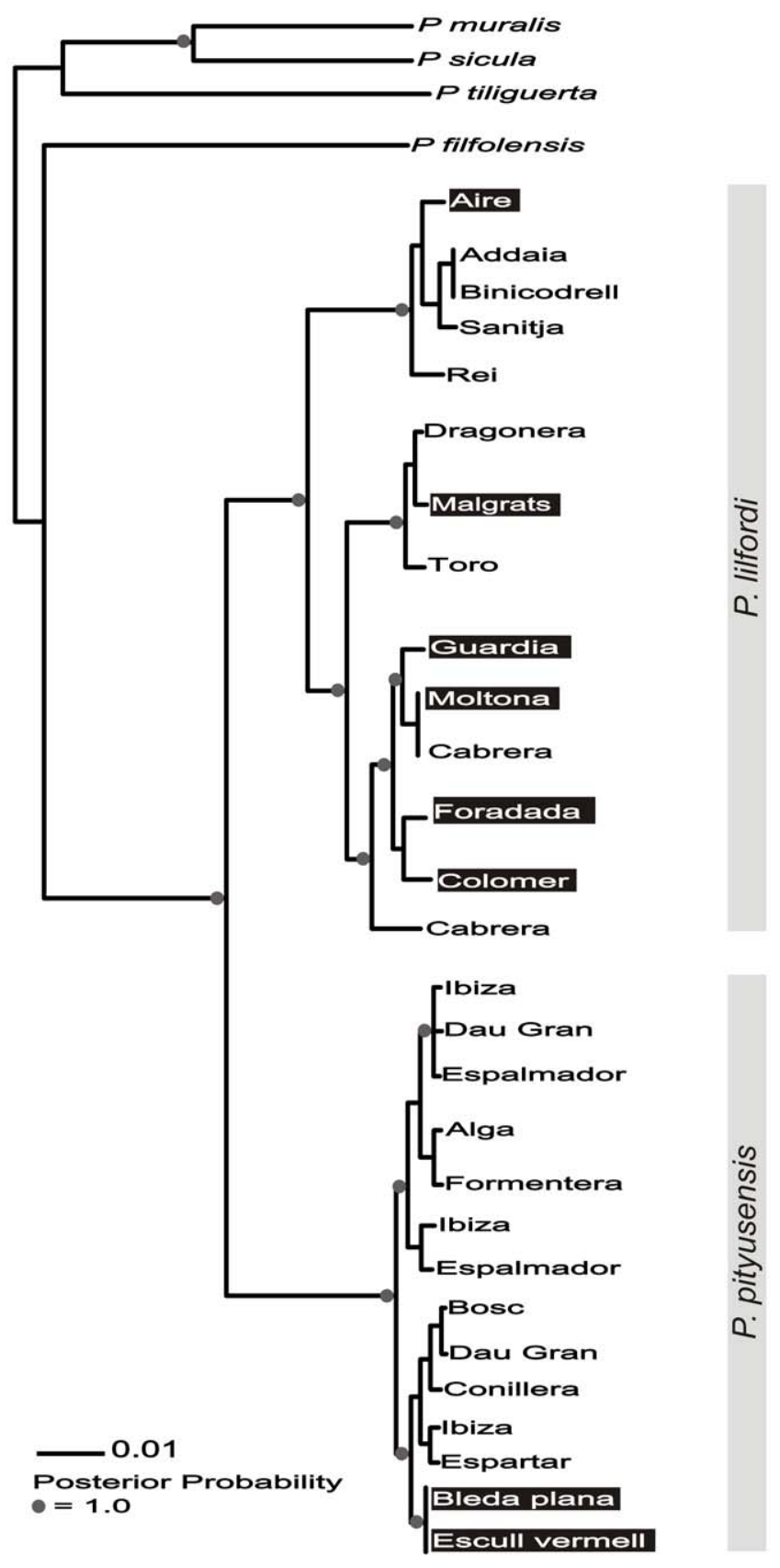

Figure 3. The mtDNA consensus tree inferred by Bayesian inference. Melanic $P$. lilfordi/P. pityusensis populations are highlighted in black. Circles are placed on nodes in which posterior probabilities were $\geq 0.9$.

doi:10.1371/journal.pone.0053088.g003

access EF694768, EF694794, EF694817, EF990552, EU006717, JX852045, JX852048, JX852051-JX852053, JX852055, JX852057-JX852059, JX852063, JX852066, JX852081, JX852091，JX852093-JX852094, JX852099, JX852104, JX852118, JX852120, JX852122-JX852123, JX852125, JX852127, JX852129), from $P$. tiliguerta (GenBank access JX852110-JX852111, JX852113-JX852114, JX852116JX852117, JX852139-JX852141) and P. filfolensis (GenBank access JX852109, JX852112, JX852115, JX852138). Previously published $P$. lilfordi sequences [23] have also been used in this study.
Haplotype phases for $m c 1 r$ were resolved for heterozygotic individuals using DnaSP software v5.10 [28] which implements an algorithm from the program PHASE [29,30,31]. The same software was used to obtain estimates of sequence diversity and compute the nucleotide diversity at synonymous, nonsynonymous, and silent sites, following Nei and Gojobori [32]. Neutrality was tested with Tajima's D test [33] and Fu's F test [34] using DnaSP [28].

A $m c 1 r$ haplotype network was constructed using the program TCS v.1.21 [35] to examine whether or not melanism was associated with the overall $m c 1 r$ genealogy. TCS creates a network using statistical parsimony $[36,37]$. The probability of parsimony for linking haplotypes was set at the 95\% level.

Phylogenetic trees were obtained using Bayesian inference on the haplotypes (MrBayes v.3.1.2 [38]). Two MCMC samplers were run in parallel (4 chains each, temperature (no lo llama el "heating parameter") parameter set at 0.2) starting from a random tree for $1.3 \times 10^{6}$ generations (samples recorded every 100 generations). In both sampling runs, stationarity of the Markov Chain was determined by stable split-standard deviations and stable sampled log likelihood values. The posterior sample of trees that followed burn-in were combined into a majority-rule consensus tree and used to estimate posterior node probabilities.

\section{Results}

Assignment of the 27 Balearic populations and other Podarcis species to melanic and non-melanic sets is shown in Table 1. Individuals from Foradada, Guardia, Moltona, Aire and Escull Vermell islands within the melanic group of 8 populations also show blue spots. Melanic individuals from Aire and Malgrats populations also show brown dorsal spots and blue ventral ocelli. The non-melanic group comprises 19 populations. In this group, the most dominant dorsal colour is green (10 populations), followed by brown (8 populations). The presence of black, blue and/or yellow spots is less common. In general, non-melanic populations have light ventral colour.

The $720 \mathrm{bp} m c 1 r$ sequence provided 146 haplotypes, corresponding to 45 segregating sites, across $P$. lilfordi, $P$. pityusensis, $P$. filfolensis and $P$. tiliguerta specimens. The observed changes are displayed against the $P$. sicula reference sequence (Table 2). There were 32 synonymous and 13 nonsynonymous substitutions. We show the locations of nonsynonymous substitutions on the MC1R protein (Fig. 1). Substitutions which encode for different amino acids are V88I, V92E, V92L, D116N, I139V, F146L, M202V, Q210H, C250W, F255C, T263S, C272S, and A296P, mostly corresponding to the transmembrane domain of the protein.

Two C-T transitions at sites 483 and 696 are specific to $P$. tiliguerta, and they represent synonymous substitutions: $\mathrm{Val}^{161}$ and $\mathrm{Thr}^{232}$. Two similar changes at sites 568 and 594 are present in Podarcis filfolensis. These changes correspond to Leu ${ }^{190}$ and Ile ${ }^{198}$.

Six sites (318, 329, 402, 405, 795 and 879) are divergent between $P$. sicula and $P$. lilfordi, $P$. pityusensis, $P$. filfolensis and $P$. tiliguerta. The T-C transition at site 329 is the only nonsynonymous change. However, sites 318, 402 and 405 are not variable in $P$. filfolensis. Two populations of $P$. lilfordi (Addaia and Binicodrell) did not show substitutions at site 318 . Thirty-nine sites within the $m c 1 r$ gene fragment were variable within one (or more) of the insular populations of the Balearic Archipelago. Three sites in the $m c 1 r$ sequence could be considered potential mutational hot spots (SNPs): c.390A $>$ R, c.645C $>$ Y and c.804C $>$ Y positions.

We tested for associations between $m c 1 r$ variants and colour categories. Because of the high mclr diversity observed, PHASE could not assign haplotype identities to all genotypes with high 
Table 3. Genetic diversity parameters based on mc1r gene sequences (720 bp) and mtDNA ( $2370 \mathrm{bp}$ ).

\begin{tabular}{|c|c|c|c|c|c|c|c|c|c|c|c|c|c|c|c|c|}
\hline & \multicolumn{8}{|c|}{ MC1R } & \multicolumn{8}{|c|}{ mtDNA } \\
\hline & $\mathbf{N}$ & $\mathbf{s}$ & $\mathbf{h}$ & Hd & $\mathbf{K}$ & $\mathbf{P i}$ & D & $\mathbf{F}$ & $\mathbf{N}$ & $\mathbf{s}$ & h & Hd & $\mathbf{K}$ & $\mathbf{P i}$ & D & $\mathbf{F}$ \\
\hline P. lilfordi & 92 & 30 & 35 & $\begin{array}{l}0.955 \\
(0.009)\end{array}$ & 3.634 & $\begin{array}{l}0.005 \\
(0.001)\end{array}$ & $-1.242^{\mathrm{ns}}$ & $-1.237^{\mathrm{ns}}$ & 36 & 154 & 23 & $\begin{array}{l}0.965 \\
(0.016)\end{array}$ & 47.535 & $\begin{array}{l}0.020 \\
(0.001)\end{array}$ & $0.929^{\text {ns }}$ & $1.271^{\mathrm{ns}}$ \\
\hline P. pityusensis & 44 & 14 & 23 & $\begin{array}{l}0.958 \\
(0.014)\end{array}$ & 3.050 & $\begin{array}{l}0.004 \\
(0.001)\end{array}$ & $-0.163^{n s}$ & $-0.324^{\mathrm{ns}}$ & 21 & 45 & 17 & $\begin{array}{l}0.976 \\
(0.023)\end{array}$ & 9.533 & $\begin{array}{l}0.004 \\
(0.001)\end{array}$ & $-0.943^{\mathrm{ns}}$ & $-1.386^{\mathrm{ns}}$ \\
\hline Other species & 8 & 12 & 6 & $\begin{array}{l}0.929 \\
(0.084)\end{array}$ & 4.464 & $\begin{array}{l}0.006 \\
(0.001)\end{array}$ & $-0.178^{\mathrm{ns}}$ & $0.025^{\mathrm{ns}}$ & 4 & 259 & 3 & $\begin{array}{l}0.833 \\
(0.222)\end{array}$ & 136.500 & $\begin{array}{l}0.058 \\
(0.023)\end{array}$ & $-0.537^{\mathrm{ns}}$ & $-0.595^{\mathrm{ns}}$ \\
\hline Melanic & 44 & 22 & 18 & $\begin{array}{l}0.900 \\
(0.031)\end{array}$ & 3.476 & $\begin{array}{l}0.005 \\
(0.001)\end{array}$ & -1.029 & $-1.143^{\mathrm{ns}}$ & 18 & 202 & 10 & $\begin{array}{l}0.935 \\
(0.032)\end{array}$ & 56.451 & $\begin{array}{l}0.024 \\
(0.005)\end{array}$ & $-0.244^{\mathrm{ns}}$ & $1.143^{\mathrm{ns}}$ \\
\hline Non melanic & 92 & 34 & 43 & $\begin{array}{l}0.968 \\
(0.007)\end{array}$ & 3.582 & $\begin{array}{l}0.005 \\
(0.001)\end{array}$ & $-1.493^{\mathrm{ns}}$ & $-1.972^{*}$ & 39 & 226 & 30 & $\begin{array}{l}0.977 \\
(0.014)\end{array}$ & 78.260 & $\begin{array}{l}0.033 \\
(0.002)\end{array}$ & $1.591^{\mathrm{ns}}$ & $1.424^{\mathrm{ns}}$ \\
\hline \multicolumn{17}{|c|}{$\begin{array}{l}\mathrm{N}=\text { number of sequences: } \mathrm{S}=\text { number of segregating sites; } \mathrm{h}=\text { number of haplotypes; } \mathrm{Hd}=\text { haplotype diversity; } \mathrm{K}=\text { number of pairwise differences; } \mathrm{Pi}=\text { nucleotide } \\
\text { diversity; } \mathrm{D} \text { Tajima's } \mathrm{D}(1989) \text { Fu's } \mathrm{F} \text { and Li's } \mathrm{F}(1993) \text {. SE is indicated in parentheses. } \\
{ }^{n} \text { s not significant, }{ }^{*} \mathrm{P}<0.05 \text {. } \\
\text { The melanic individuals belong to } P \text {. liffordi and } P \text {. pityusensis insular populations. }\end{array}$} \\
\hline
\end{tabular}

probabilities. Tests were therefore based on direct sequence, incorporating heterozygotic sites, rather than on phased haplotypes. First, we examined whether any specific changes in the sequence were associated with melanic phenotypes. No substitutions were common to all melanic individuals. A contingency table test was used to analyze possible associations between each polymorphic position and the melanic phenotype. The only significant deviation association was detected in the $681 \mathrm{nt}$ $\left(\chi^{2}=25.17, \mathrm{P}<0.001\right)$ but this was an $\mathrm{A} / \mathrm{G}$ synonymous change. Alleles containing an A were more abundant in melanic populations.

The DNA network results are shown in Figure 2. The melanic populations of Foradada, Colomer, Guardia and Moltona $(P$. lilfordi) share some common synonymous changes at $\mathrm{Thr}^{111}$ and $\mathrm{Ser}^{227}$. However, these substitutions are not shared with the $P$. lilfordi from Aire and Malgrats, or Escull Vermell and Bleda Plana melanic populations of $P$. pityusensis.

We also examined whether substitutions in the first $210 \mathrm{bp}$ of the gene might be associated with melanism by sequencing the entire $m c 1 r$ gene for a smaller group of 6 individuals from 3 melanic (Moltona, Guardia and Malgrats) and 3 non-melanic (Cabrera, Dragonera and Formentera (P. Trocadors)) islets. Sequences were compared to $P$. sicula sequence and seven substitutions were detected. Six of these substitutions were present in all populations and were synonymous: $\mathrm{Pro}^{14}, \mathrm{Pro}^{21}, \mathrm{Asn}^{24}$, $\mathrm{Leu}^{43}$, Phe ${ }^{52}$ and Lys ${ }^{64}$. One non-synonymous change, G41D, was detected (Fig. 1). However, this caused an amino acid substitution that had no effect on protein charge. This substitution was observed in the melanic populations from Moltona and Guardia but not in the melanic population from Malgrats. There were no indels within the initial 210 base pairs of the mc1r sequence. There were no associations between phenotype categories (green and brown, blue and yellow spots and ventral colour) and the observed amino acid or synonymous substitutions in $m c 1 r$.

\section{Gene Diversity and Selective Effects}

The mitochondrial gene tree that was inferred for the same individuals is shown in Figure 3. The tree is concordant with the two species and also shows clear island phylogeographical patterns within species. Both melanic and non-melanic populations were found in the three main mtDNA lineages in $P$. lilfordi but were only detected within a single mtDNA lineage in $P$. pityusensis. The $m c 1 r$ gene tree shows low posterior support for some nodes. However, splits in the tree do not correspond to melanic/non-melanic population divisions. Unlike the mtDNA tree, the major split within the tree does not correspond to the two species.

Table 3 shows the diversity estimates for the mclr gene and the mtDNA. Both loci have greater diversity in $P$. lilfordi than in $P$. pityusensis. Also, the melanic insular populations are less diverse than the non-melanic ones.

No statistically significant signature of selection was detected using Tajima's D test [33]. Values were slightly negative, with the exception of $P$. lilfordi and non-melanic groups that present slightly positive $\mathrm{D}$ values for mtDNA. The results from Fu's and Li's tests [34] were similar, except in the case of the non-melanic group (for the $m c 1 r$ gene), for which $\mathrm{F}$ statistic is negative, and significant at $5 \%(\mathrm{P}<0.05)$.

\section{Discussion}

Substitutions in the $m c 1 r$ gene of endangered Balearic Island Podarcis lizards do not appear to be related to either melanism or other components of the considerable colour pattern variation among islands.

Recent studies on pigmentation genes and their functions have provided evidence that pigment gene function is largely conserved across vertebrate taxa and can influence adaptive coloration, often in predictable ways [1]. The $m c 1 r$ gene is highly conserved among vertebrates and has a relatively simple genetic structure. This has facilitated its identification in a diversity of taxa, including lizards. The majority of these studies try to associate a punctual nonsynonymous sequence change with a discrete colour polymorphism.In some cases, identical mutations at homologous positions in diverse taxa have been found to led to the same or similar phenotypes [1].

The $m c 1 r$ gene is polymorphic in the studied populations. We found 45 variable positions with respect to the published $m c 1 r$ gene sequence of $P$. sicula and three of these positions could be considered as hot spots due to their high mutation frequency. As expected under neutral evolution, synonymous changes are most numerous but thirteen substitutions encode for different amino acids, and most of them correspond to the transmembrane domain of the protein. Much of the genetic diversity in $m c 1 r$ appears to reflect the patterns observed in the mtDNA, which have been 
interpreted in terms of the historical biogeography of these species $[22,23]$. For example, $P$. lilfordi shows much greater genetic diversity (in both loci) than $P$. pityusensis. Previous mtDNA analyses showed that was likely to have originated from ancient isolation on the major islands of Mallorca, Menorca and Cabrera during the Pliocene [22,23].

Nunes et al. [16] detected two associations between $m c 1 r$ variants and ecologically relevant phenotypes in the European ocellated lizard Lacerta lepida, a genus related to Podarcis. The first is a nonconserved and derived substitution (T162I) associated with the presence of brown scales ("nevadensis" phenotype), while the second substitution (S172G) was associated with the presence of black scales in both $L$. l. lepida and L. l. iberica. However, they did not detect mutations associated with the higher proportion of black scales in L. l. iberica. Here, the nucleotide positions 162 and 172 were not variable among the very polymorphic populations of Podarcis.

With some exceptions [5] melanism is also associated with substitutions at the $m c 1 r$ locus in a variety of mammals and birds, including domestic [39,40] and wild species [41]. In this case structural mutations (deletions) are thought to be responsible for the melanic phenotype. There were no deletions in the $m c 1 r$ gene sequence in melanic populations of Podarcis lilfordi and Podarcis pityusensis, suggesting that this is not the case here. The unique substitutions that we have observed in the melanic populations: Foradada, Colomer, Guardia and Moltona ( $P$. lilfordi), are synonymous changes at $\mathrm{Thr}^{111}$ and $\mathrm{Ser}^{227}$. However, the $P$. lilfordi Aire and Malgrats island populations, and the P. pityusensis Escull Vermell and Bleda Plana island populations, are melanic, but do not share these substitutions. It is therefore very difficult to believe they play a role in melanism in any of these species. Similar findings have recently been reported for the side-blotched lizard, Uta stansburiana [12].

The presence of a dark phenotype is thought to be a relict character in cordylic lizards [42]. However, it has been hypothesized that this character is under quite strong selection

\section{References}

1. Hubbard JK, Uy JAC, Hauber ME, Hoekstra HE, Safran RJ (2010) Vertebrate pigmentation: from underlying genes to adaptive function. Trends Genet 26 : 231-239.

2. Robbins LS, Nadeau JH, Johnson KR, Kelly MA, Roselli-Rehfuss L, et al. (1993) Pigmentation phenotypes of variant extension locus alleles result from point mutations that alter MSH receptor function. Cell 72: 827-834.

3. Takeuchi S, Suzuki S, Hirose S, Yabuuchi M, Sato C, et al. (1996) Molecular cloning and sequence analysis of the chick melanocortin 1-receptor gene. Biochim Biophys Acta 1306: 122-126.

4. Schioth HB, Haitina T, Ling MK, Ringholm A, Fredriksson R, et al. (2005) Evolutionary conservation of the structural, pharmacological, and genomic characteristics of the melanocortin receptor subtypes. Peptides 26: 1886-1900.

5. Anderson TM, vonHoldt BM, Candille SI, Musiani M, Greco C, et al. (2009) Molecular and evolutionary history of melanism in North American gray wolves. Science 323: 1339-1343.

6. McRobie H, Thomas A, Kelly J (2009) The genetic basis of melanism in the gray squirrel (Sciurus carolinensis). J Hered 100: 709-714.

7. Guo XL, Li XL, Li Y, Gu ZL, Zheng CS, et al. (2010) Genetic variation of chicken $M C 1 R$ gene in different plumage colour populations. Br Poult Sci 51: 734-739.

8. Gross JB, Borowsky R, Tabin CJ (2009) A novel role for Mc1r in the parallel evolution of depigmentation in independent populations of the cavefish Astyanax mexicanus. PLoS genetics 5: e1000326.

9. Rosenblum EB, Rompler H, Schoneberg T, Hoekstra HE (2010) Molecular and functional basis of phenotypic convergence in white lizards at White Sands. Proc Natl Acad Sci USA 107: 2113-2117.

10. Herczeg G, Matsuba C, Merilä J (2010) Sequence variation in the melanocortin1 receptor gene $(M c 1 r)$ does not explain variation in the degree of melanism in a widespread amphibian. Ann Zool Fennici 47: 37-45.

11. Corso J, Gonçalves GL, de Freitas TRO (2012) Sequence variation in the melanocortin-1 receptor $(M C 1 R)$ pigmentation gene and its role in the cryptic coloration of two South American sand lizards. Genet Mol Biol 35: 81-87. in Podarcis due to its impact on thermoregulation [20]. Given the low prevalence of melanism in other Podarcis, it seems unlikely that melanism is the ancestral condition for these species. If we assume that the mtDNA branching pattern reflects the true species/ population history then the most parsimonious explanation is that the ancestral condition is the non-melanic colour seen in most other Podarcis. If this is the case here then melanism has clearly evolved several times within Balearic Podarcis. However, our statistical tests on mclr provided no support for the hypothesis that that this can be attributed to different selection regimes on different melanic populations.

Podarcis coloration therefore seems to be attributable to other loci. For example, agouti signaling protein (asip) is important in melanin synthesis and multiple mutations in this gene are associated with colour variation. However, compared with $m c 1 r$, far fewer studies have been carried out on wild populations and also the molecular changes associated with colour variation are different with both coding and regulatory regions being implicated. To date, agouti-like sequences have not been reported in reptiles. In addition to melanin pigments, animal coloration can involve carotenoid pigments and pterins, but the genetic mechanisms involved in these pathways are poorly understood [1].

Balearic Island Podarcis populations exhibit a wide variety of colour variants, with morphs ranging from completely melanic to quite light-coloured individuals, although green-brown pigmentation is the most frequent morph. Sequencing of the mo1r gene in individuals with different morphological phenotypes has not revealed a clear correlation between mutations and/or deletions and these different colour morphs.

\section{Author Contributions}

Conceived and designed the experiments: MMR JAG RPB. Performed the experiments: JMB VR VPM AP. Analyzed the data: JMB VR MMR. Contributed reagents/materials/analysis tools: VPM BT MMR. Wrote the paper: JMB VR RPB MMR.

12. Micheletti S, Parra E, Routman EJ (2012) Adaptive Color Polymorphism and Unusually High Local Genetic Diversity in the Side-Blotched Lizard, Uta stansburiana. PLoS One 7: e47694.

13. Raia P, Guarino FM, Turano M, Polese G, Rippa D, et al. (2010) The blue lizard spandrel and the island syndrome. BMC Evol Biol 10: 289.

14. Bagnara JT, Fernandez PJ, Fujii R (2007) On the blue coloration of vertebrates. Pigment Cell Res 20: 14-26.

15. Parker AR (1998) The diversity and implications of animal structural colours. J Exp Biol 201: 2343-2347.

16. Nunes VL, Miraldo A, Beaumont MA, Butlin RK, Paulo OS (2011) Association of $M c 1 r$ variants with ecologically relevant phenotypes in the European ocellated lizard, Lacerta lepida. J Evol Biol 24: 2289-2298.

17. Harris DJ, Arnold EN (1999) Relationships of Wall Lizards, Podarcis (Reptilia: Lacertidae) Based on Mitochondrial DNA Sequences. Copeia 1999: 749-754.

18. Arnold EN, Arribas O, Carranza S (2007) Systematics if the Palaearctic and Oriental lizard tribe Lacertini (squamata: Lacertidae: Lacertinae), with descriptions of eight new genera. Zootaxa 1430: 1-86.

19. Eisentraut M (1954) Der inselmelanismus der Eidechsen und seine Entstechung im Streit der Meinungen. Zool Anz 152: 317-321.

20. Kramer G (1949) Über Inselmelanismus bei Eidechsen. Z Indukt Abstamm Ver 83: $157-164$.

21. Eisentraut M (1949) Die Eidechsen der spanische Mittelmeerinseln und ihre Rassenaufspaltung im Lichte der Evolution. Mitt Zool Mus Berlin 26: 1-225.

22. Brown RP, Terrasa B, Perez-Mellado V, Castro JA, Hoskisson PA, et al. (2008) Bayesian estimation of post-Messinian divergence times in Balearic Island lizards. Mol Phylogenet Evol 48: 350-358.

23. Terrasa B, Pérez-Mellado V, Brown RP, Picornell A, Castro JA, et al. (2009) Foundations for conservation of intraspecific genetic diversity revealed by analysis of phylogeographical structure in the endangered endemic lizard Podarcis lilfordi. Diversity Distrib 15: 207-221.

24. Hartmann M (1953) Die Rassenaufspaltung der Blearischeninsel Eidechsen. Zool Jb Phys 64: 86-96. 
25. Pérez-Mellado V, Salvador A (1988) The Balearic lizard, Podarcis lilfordi (GUNTHER, 1874) of Menorca. Arquiv Mus Bocage 1.

26. Salvador A, Pérez-Mellado V (1984) The Amphibians and Reptiles of the Pytiusic Islands. In: Khubièr K, Alcover JA, d'Arellano Tur GC, editors. Biogeography and Ecology of the Pityusic Islands. The Hague: Dr. W. Junk Publishers. 429-439.

27. Pinho G, Rocha S, Carvalho B, Lopes S, Mourão S, et al. (2010) New primers for the amplification and sequencing of nuclear loci in a taxonomically wide set of reptiles and amphibians. Conserv Genet Resour 2: 181-185.

28. Librado P, Rozas J (2009) DnaSP v5: a software for comprehensive analysis of DNA polymorphism data. Bioinformatics 25: 1451-1452.

29. Stephens M, Donnelly P (2003) A comparison of bayesian methods for haplotype reconstruction from population genotype data. Am J Hum Genet 73: 11621169 .

30. Stephens M, Scheet $P$ (2005) Accounting for decay of linkage disequilibrium in haplotype inference and missing-data imputation. Am J Hum Genet 76: 449462.

31. Stephens M, Smith NJ, Donnelly P (2001) A new statistical method for haplotype reconstruction from population data. Am J Hum Genet 68: 978-989.

32. Nei M, Gojobori T (1986) Simple methods for estimating the numbers of synonymous and nonsynonymous nucleotide substitutions. Mol Biol Evol 3: 418-426.

33. Tajima F (1989) Statistical method for testing the neutral mutation hypothesis by DNA polymorphism. Genetics 123: 585-595.

34. Fu YX, Li WH (1993) Statistical tests of neutrality of mutations. Genetics 133: 693-709.
35. Clement M, Posada D, Crandall KA (2000) TCS: a computer program to estimate gene genealogies. Mol Ecol 9: 1657-1659.

36. Templeton AR, Sing CF (1993) A cladistic analysis of phenotypic associations with haplotypes inferred from restriction endonuclease mapping. IV. Nested analyses with cladogram uncertainty and recombination. Genetics 134: 659669.

37. Templeton AR, Crandall KA, Sing CF (1992) A cladistic analysis of phenotypic associations with haplotypes inferred from restriction endonuclease mapping and DNA sequence data. III. Cladogram estimation. Genetics 132: 619-633.

38. Huelsenbeck JP, Ronquist F (2001) MRBAYES: Bayesian inference of phylogenetic trees. Bioinformatics 17: 754-755.

39. Kerje S, Lind J, Schutz K, Jensen P, Andersson L (2003) Melanocortin 1receptor $(M C 1 R)$ mutations are associated with plumage colour in chicken. Anim Genet 34: 241-248.

40. Kijas JMH, Wales R, Törnsten A, Chardon P, Moller M, et al. (1998) Melanocortin Receptor $1(M C 1 R)$ Mutations and Coat Color in Pigs. Genetics 150: 1177-1185.

41. Nachman MW, Hoekstra HE, D'Agostino SL (2003) The genetic basis of adaptive melanism in pocket mice. Proc Natl Acad Sci USA 100: 5268-5273.

42. Daniels SR, Mouton P, Du Toit DA (2004) Molecular data suggest that melanistic ectotherms at the south-western tip of Africa are the products of Miocene climatic events: evidence from cordylid lizards. J Zool 263: 373-383.

43. Garcia-Borron JC, Sanchez-Laorden BL, Jimenez-Cervantes C (2005) Melanocortin-1 receptor structure and functional regulation. Pigment Cell Res 18: 393410. 